\title{
Level of Awareness of Social Media Users on Cyber Security: Case Study among Students of University Tun Hussein Onn Malaysia
}

\author{
Shahidah Hamzaha ${ }^{a}$ Fauziah Ani ${ }^{b}$, Norizan Ramelic ${ }^{\text {, Noranifitri Md Nord, Harliana Halim }}{ }^{\mathrm{e}}$, Adi Syahid \\ Md Alif , Riki Rahmang, Nizam Attan ${ }^{\text {h }}$, Khairol Anuar Kamri
}

\author{
A, b,c,d,e,f,g,h,i \\ Focus Group Sustainable Community, Culture \& Economic Development, \\ Department of Social Sciences, \\ Centre for General Studies and Co-curricular, \\ Universiti Tun Hussein Onn Malaysia \\ 86400, Malaysia
}

Article History: Received: 11 January 2021; Accepted: 27 February 2021; Published online: 5 April 2021

\begin{abstract}
The vast development of modern technology has resulted in a great impact on the life of children today and extended to teenagers group. This research was conducted to identify the level of awareness of university students on cybercrime. For this research purpose, the respondents involved were among the students of Universiti Tun Hussein Onn Malaysia, Pagoh campus. The total number of respondents that was targetted for this research was around 100 people. The instrument used was in quantitative form using questionnaire given to the respondents. The research outcome found that the level of university students' awareness towards cyber security is at moderate level. Therefore, many proactive steps need to be implemented by the stakeholders so that issues that are relevant to cybercrime can be reduced and later be rid of.
\end{abstract}

Keywords: Awareness, social media users, cyber security, quantitative research

\section{Introduction}

In the world evolution, people have created sophisticated innovations that could ease daily lives and enhance the standard of living and human charity. With rapid advancement of technology and science development, technological tools play a really significant role in our daily lives. Communication between people is also better and can be made regardless of the distance. The dissemination of information can be made even faster. The availability of network and wireless network as a tool of communication has overcome the use of other communication tools such as telephone, email, fax machine and many more. The research outcome carried out by the Internet World Stat (2009) showed an increase of 39.3\% internet users between the year 2000 until 2009 where Malaysia is included among the Top 10 in Asia with 16.9 million users in 2009. This shows that there has been a change in terms of communication technology aspect in daily life.

The spread of information is a type of activity or action that involves wide information chanelling. Every information spreaded has its own message and particular agenda. According to Mohd Azul Mohamad Salleh et. al (2016), the development of online system or application has brought about changes towards the life of society in processing, sharing and spreading information. In terms of time, the spread of information through wireless network is much more effective. However, the culture of information sharing eletronically has its own risk.

Based on the research by the Malaymail (2019), 53\% of Malaysian citizens are not able to differentiate between rumours and valid information. The spread of information without knowing its validity will lead to negative impacts such as fraud, phobia, cyber bully, slander, incitement and provocation that could disrupt the security of the country.

Hence, the level of awareness of social media users towards cyber security is important. Based on the research by Adnan \& Kamaliah (2000), the value of cyber security needs to be instilled to the whole social media users so that the risk for every information sharing in social media is made known. The attitude of social media users that easily trusts strangers will open the room for other crimes such as rape, robbery and scam.

\section{Literature Review}

The development of social media applications in Malaysia is in line with the growth of communication technology tools and instruments such as mobile phones and personal laptops. According to Mano Govindraju (Tech Data Management director) (2018), the government's action in introducing the framework towards Industry 4.0 (IR 4.0) is the preparation of the country to strengthen its structuring reformation. Apart from that, in positive aspect, cyber threat also contributes in self preparation before digital transformation fully becomes a reality. Therefore, cyber security is very crucial in ensuring the well-being of society (Norhafzan Jaafar, 2018).

In the year 2018, Malaysian Communication and Multimedia Commission (MCMC) has detected at least 15000 fake news and it was found that $100 \%$ originated from Malaysian citizens, $1 \%$ from it was the Malaysian citizens residing in other countries. According to the official portal of MCMC, the Communication and Multimedia Act 1998 aims to prepare a set of regulation provision that is based on the generic definition of market and 
communication and multimedia industrial activities. The focus of MCMC is to restrict the factors that could disrupt the well-being and solidarity of Malaysian citizens through investigation.

Based on the report from The ASEAN Post (2018), 71\% Z generation in Malaysia acquired news through social media. This generation usually gets information from influencers' opinions which are biased and full of prejudice. This will lead to limited perspectives and are closed towards right opinion.

The research from Batat. W., (2009) found that technology plays a really important role to a teenager's life. Technology is used for social purposes, entertainment, building self-esteem, and helps in the development of technological skills. Teenagers are also inclined towards learning many things through media and skills like the competency in using technology and social skills of teenagers can be developed with the use of technology like mobile phones.

Claus J.Tully (2003) from the German Youth Institute explained the interaction among youth with latest technology and involves disintegration of social relationship including technology in society, technology as the platform for experience and basis to individual's future, social differentiation technology, technology for mobility and so on. In short, the way to face environmental and social changes has changed with modern technology. The research also opined that what is important is comfort, ease and happiness in daily life with the presence of modern technology.

From the research outcome by Mohammed M. A., Maroof E. Y., Ali. Thamer and Huda I. (2015), the focus on information sharing factor that influences the participative behaviour of government staff found that good and bad qualities will influence the attitude in the society such as the quality of information that can enhance belief and cooperation in organisation and competition as information is described as an asset to protect position, status and identity. This mindset has caused the practice of knowledge sharing become a huge challenge among the youth.

The perspective and opinion of one individual is influenced by information regardless of the form of printed or digital. Suriati Ghazali, Azilah M. Nor and Jabil Mapjabil (2009) analysed the role of media in spreading information about transsexual lifestyle in Malaysia found that the access to transsexual content in news, and broadcasting and entertainment industry has influenced Malaysian society to accept and practise this lifestyle.

Mohd Anuar Ramli, Mohammad Aizat Jamaludin, Abdul Qayyum Aminnuddin and Mohammad Naqib Hamdan (2015) conducted a research on the spread of false information about halal products and its impact towards halal industry. The result found that the development of information technology influences the development of halal industry. The spread of false halal information will lead to uncertainty in society as halal issue is sensitive in Islamic society. The power of stakeholders will be questioned when the spread of false halal information occurs. The society started to lose faith towards the authority especially the religious group and they will be perceived as incompetent in carrying out their duty. Muslim users will become sceptical towards the product despite explanation being made by the authority like JAKIM. Therefore, the spread of false halal information could impact the country's halal industry and halal product market negatively.

The research by Stanford (2016) aimed to evaluate the capability of students in the United States of America involving students of high school and colleges in 12 states on the access of information source. The outcome found that the youth in USA were able to put a threat towards democracy as students are easily influenced by the appearance of website and easily trust the material of 'Sponsored Content' as a news article, while it is not. Most upper form students could not differentiate trusted or fake news sources apart from Facebook. The researcher views this thing as the responsibility of the people to ensure users are ethical and careful.

\section{Methodology}

This research used quantitative approach. The main instrument in data collection process was the questionnaire form. This questionnaire form was amended from past research of Che Hasniza Che Noh et. Al (2014) and Abdullah et. Al (2016). This questionnaire contains four parts as in Table 1 which is:

Table 1: Parts of Questionnaire

\begin{tabular}{lll}
\hline No & Component & Parts of Questions \\
\hline 1 & Respondents' profiles & Part I: General Profiles of Respondents \\
2 & Information on social media & Part II: Information on social media used \\
3 & Awareness level of social media users & $\begin{array}{l}\text { Part III: Knowledge and awareness about social } \\
\text { media }\end{array}$ \\
4 & $\begin{array}{l}\text { Knowledge and awareness about cyber security } \\
\text { and its threat }\end{array}$ & $\begin{array}{l}\text { Part IV: Knowledge and awareness about cyber } \\
\text { security and its threat. }\end{array}$ \\
\hline
\end{tabular}

The respondents consisted of 100 students of Universiti Tun Hussein Onn Malaysia who have social media account. In this research, easy random sampling method was used. The collected data were analysed using the Statistical Package for Social Sciences (SPSS) software. Descriptive analysis was performed on the demography of the respondents to know the number of respondents tested such as gender, age, education level through frequency distribution and percentage technique. The mean value and standard deviation were used for questions in part II, III and IV to evaluate the level of knowledge and awareness on the threat of cyber security as a result of social media use.

\subsection{Discussion}




\subsection{Respondents' General Profiles}

There are four (4) questions in this part which are; (i) gender, (ii) age, (iii) ethnicity and (iv) education level. Information from this part aimed to know the respondents' background who were involved in the research. Table 2 below shows the frequency distribution and the percentage of respondents involved.

Based on Table 2, this research's respondents were made up of 100 respondents of which 53\% were female students and $47 \%$ were male students. In terms of age, $21 \%$ were between 18 and 20 years old. $76 \%$ were between 21 to 23 years old and $3 \%$ were 24 years old and above.

In terms of ethnicity, it was found that the majority of the respondents were Chinese with 46 people or equals to $46 \%$. This is followed by Malay ethnicity with 29 people or $29 \%$. Next is Indian ethnicity with 20 people, equals to $20 \%$ and others are 5 people, with $5 \%$.

While in terms of education, most respondents were in Bachelor's Degree level, followed by 3 respondents with educational background at diploma level, bringing it to 3\%, and the rest was respondents at Master's Degree level with $2 \%$.

Table 2: Respondents' Profiles

$$
\text { Respondents' background } \quad \text { Frequency } \quad \text { Percentage (\%) }
$$

\begin{tabular}{|c|c|c|c|}
\hline \multirow[t]{3}{*}{$\mathrm{i}$} & Gender & & \\
\hline & a) Male & 47 & 47 \\
\hline & b) Female & 53 & 53 \\
\hline \multirow[t]{4}{*}{ ii } & Age & & \\
\hline & $18-20$ years & 21 & 21 \\
\hline & $21-23$ years & 76 & 76 \\
\hline & 24 years and above & 3 & 3 \\
\hline \multirow[t]{5}{*}{ iii } & Ethnicity & & \\
\hline & Malay & 29 & 29 \\
\hline & Chinese & 46 & 46 \\
\hline & Indian & 20 & 20 \\
\hline & Others & 5 & 5 \\
\hline \multirow[t]{4}{*}{ iv } & Education level & & \\
\hline & Diploma & 3 & 3 \\
\hline & Bachelor's degree & 95 & 95 \\
\hline & Master's degree & 2 & 2 \\
\hline
\end{tabular}

\section{Source: Field Research 2020}

\subsection{Social media information}

There are three (3) questions in this part which are: (i) Does the respondent have social media account, (ii) types of social media owned and (iii) time estimation on the daily use of social media

Table 2: Analysis for respondents who have social media

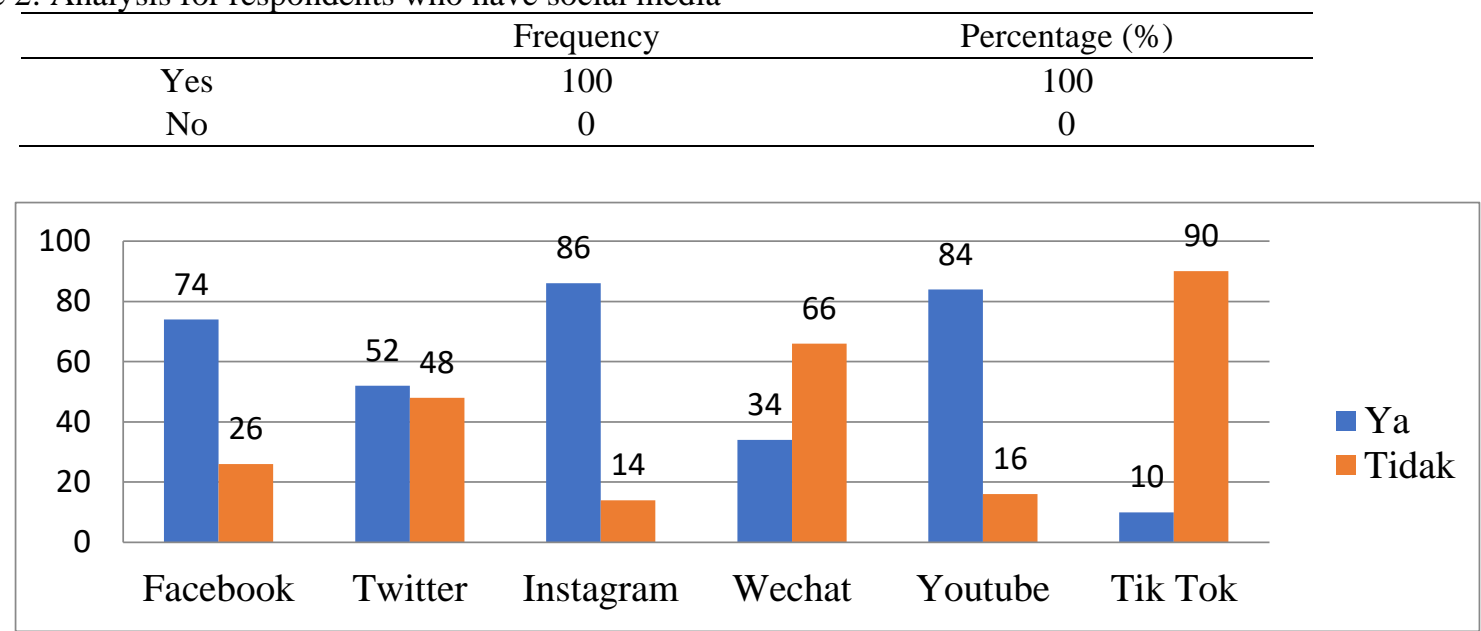

Figure 1: Types of social media used

Table 1 shows all respondents own social media account and Figure 2 summarises the types of social media that are popular among students. Social media that are most popular are Instagram, youtube, facebook and twitter. 


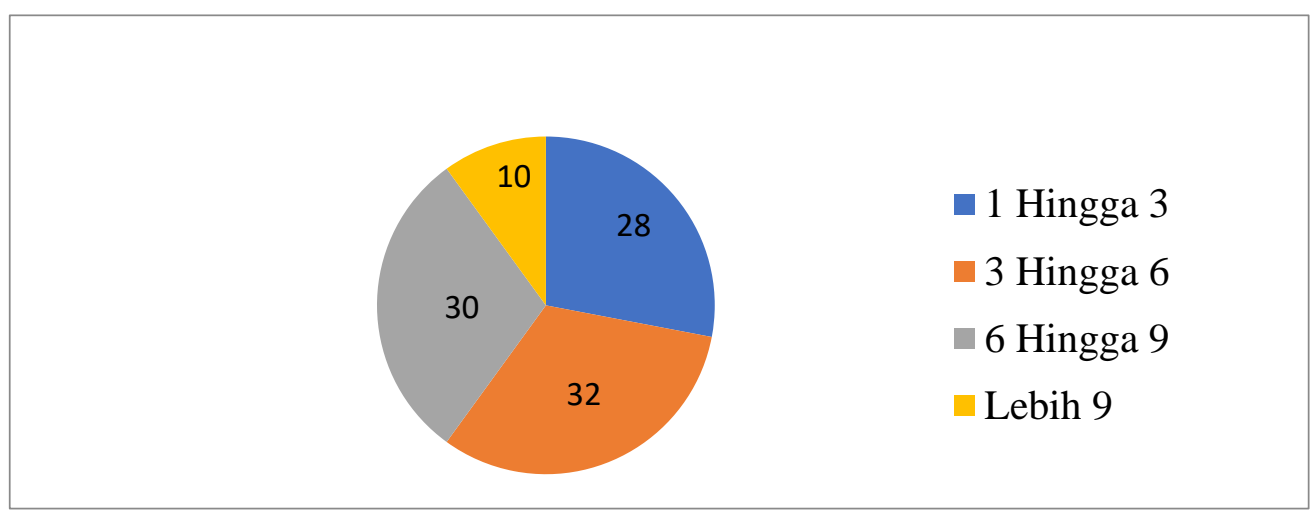

Figure 2: Time chart of social media use in a day

Based on Figure 2, most respondents allocate 3-6 hours a day to use social media, which is $32 \%$, followed by $30 \%$ of respondents who use internet for 6 to 9 hours, $28 \%$ respondents for 1 to 3 hours and $10 \%$ of respondents use social media for more than 9 hours per day.

\subsection{Knowledge of social media users}

The third part is an analysis regarding the knowledge level of respondents towards cyber threat, cyber law and cyber crime that are happening. This part comprises 10 questions.

Table 3: Knowledge level of respondents towards cyber threat, cyber law and cyber crime

\begin{tabular}{|c|c|c|c|c|c|}
\hline \multirow[t]{2}{*}{ No. } & \multirow[t]{2}{*}{ Items } & \multicolumn{2}{|c|}{ Yes } & \multicolumn{2}{|c|}{ No } \\
\hline & & Frequency & Percentage & Frequency & Percentage \\
\hline 1. & $\begin{array}{c}\text { I am aware of cyber } \\
\text { spyware through social media }\end{array}$ & 77 & $77 \%$ & 23 & $23 \%$ \\
\hline 2. & $\begin{array}{l}\text { I am aware of data theft } \\
\text { through social media }\end{array}$ & 76 & $76 \%$ & 24 & $24 \%$ \\
\hline 3. & $\begin{array}{l}\text { I am aware about cyber } \\
\text { bully crime on social media }\end{array}$ & 76 & $76 \%$ & 24 & $24 \%$ \\
\hline 4. & $\begin{array}{l}\text { I am aware of phishing on } \\
\text { social media }\end{array}$ & 42 & $42 \%$ & 58 & $58 \%$ \\
\hline 5. & $\begin{array}{l}\text { I will refer to responsible } \\
\text { agency for cyber threat }\end{array}$ & 8 & $8 \%$ & 92 & $92 \%$ \\
\hline 6. & $\begin{array}{l}\text { I am aware of cyber } \\
\text { security awareness program }\end{array}$ & 65 & $65 \%$ & 35 & $35 \%$ \\
\hline 7. & $\begin{array}{l}\text { I participate in cyber } \\
\text { security awareness campaign }\end{array}$ & 30 & $30 \%$ & 70 & $40 \%$ \\
\hline 8. & $\begin{array}{l}\text { Sebenarnya.my is a } \\
\text { website that I use to get valid } \\
\text { information }\end{array}$ & 17 & $17 \%$ & 83 & $83 \%$ \\
\hline 9. & $\begin{array}{l}\text { I am aware with whom I } \\
\text { share information on social } \\
\text { media }\end{array}$ & 75 & $75 \%$ & 25 & $25 \%$ \\
\hline 10. & $\begin{array}{l}\text { I used to be a victim of } \\
\text { cyber crime }\end{array}$ & 66 & $66 \%$ & 34 & $34 \%$ \\
\hline
\end{tabular}

The research outcome found that the level of awareness of students towards knowledge of cyber threat, cyber law and cyber crime is at moderate level. This is because from question 10, it was found that $66 \%$ of respondents used to become the victim of cyber threat such as cyber bully and scam but in question 5 that is I will refer to responsible agency for cyber threat, only 8 respondents have actually done that. This has proven that the society looks down upon the issue of cyber crime.

Questions from 1 to 4 refer to the level of knowledge on cyber crime. Based on the result from question 1 to 3 , more than $50 \%$ of the respondents are clear about cyber crime but question 4 in regard with phishing, only $42 \%$ of the respondents are aware of phishing on social media. The revelation of cyber issue needs to be made so that the society will not get involved and also become the victim of cyber crime. 
Question 8 refers to the level of knowledge about certified website in acquiring information. Although the government has implemented many actions in revealing such information, only 17 respondents are aware of the website sebenarnya.my. Question 6 and 7 are interrelated. In question 6, 65 respondents are aware and know about cyber security awareness program that has been implemented but question 7 proves that despite the awareness, only $30 \%$ of the respondents actually participate in the campaign implemented by the government. Therefore, it is crucial to enhance the shaping of attitudes in the society so that they could get away from such cyber crime.

\section{Conclusion}

The research outcome discovered that the level of awareness of social media users towards cyber security is at moderate level. This clearly shows that the level of awareness of social media users in relevant issue of cyber crime needs to be increased. The measurement upon such awareness is really important as social crime that is happening also uses social media applications.

Hence, as a social media user, we need to always ensure the validity of information before spreading it so we can avoid from becoming the fraud victim. An individual has to be alert of the information received whether it is from official source or vice versa. If the information is not from a valid source, one should not spread it as fake information sharing can impact negatively towards self, society and nation.

We must always remember the slogan 'Unsure, Don't Share'. The authority needs to play its role by taking appropriate action towards anyone who creates or spreads false information on social media. Every individual needs to use sebenarnya.my as a medium to identify the validity of information at anytime. Nevertheless, there are also students who always use internet for educational purpose

In short, the use of mobile technology has both benefits and harms. Therefore, as a responsible society, we need to be wise in restricting the spread of false information that could disrupt the prosperity and well-being of the country.

\section{References}

1. Abdullah, Z. H., Ismail, S. \& Rosli, A. N. 2016. Kebolehpercayaan Maklumat Elektronik : Tinjauan Awal Terhadap Pelajar 2nd International Convention of Islam, Science \& Education, Universiti Sains Islam Malaysia, KONGSI16: 641-647.

2. Adnan Hussein \& Kamaliah Hj. Siarap. (2000). Penggunaan Teknologi Komunikasi-Informasi Dikalangan Ahli Akademik Di Malaysia. Jurnal Komunikasi Jilid 16, 2000, muka surat 119-130. Diperoleh daripada http://journalarticle.ukm.my/4761/1/V17_2.pdf.

3. Batat, W. (2009). The Impact of Technology Development on Youth Consumption Culture: An Empirical Investigation of French Teenage' Use of Mobile Phone Device. Diperoleh daripada https://ibimapublishing.com/articles/CIBIMA/2009/968829/968829.pdf.

4. Che Hasniza Che Noh \& Mohd Yusri Ibrahim, 2014. Procedia - Social and Behavioral Sciences 134: 323329.

5. Ghazali, S., Nor, A. M. \& Mapjabil, J. (2009). Suatu Analisis Mengenai Peranan Media dalam Penyebaran Gaya Hidup Transeksual di Malaysia. Jurnal Perspektif Jil. 5 Bil. 1 (66-82) ISSN 1985 - 496X. Diperoleh daripada http://www.myjurnal.my/filebank/published_article/30111/5.PDF.

6. Mohammed M. A., Maroof E. Y., Ali. Thamer \& Huda I. (2015) What are the Electronic Information Sharing Factors that Influence the Participation Behavior in Higher Education Sector? Procedia Computer Science Volume 72, 2015, muka surat 49-58. Diperoleh daripada https://www.sciencedirect.com/science/article/pii/S1877050915035656.

7. Mohd Anuar Ramli, Mohammad Aizat Jamaludin, Abdul Qayyuum Aminnuddin, dan Mohammad Naqib Hamdan. (2015). Penyebaran Maklumat Palsu Berkaitan Produk Halal Dan Implikasinya Terhadap Industri Halal. Diperolehi daripada http://eprints.um.edu.my/14517/1/0001.pdf.

8. Mohd Azul Mohamad Salleh, Ali Salman, Mohd Nor Shahizan Ali \& Hasrul Hashim. 2016. The importance of usability features in enhancing online communication satisfaction. Malaysian Journal of Communication. 32 (1). 1-15.

9. Norhafzan Jaafar (2018), Amal 3R Sebelum Sebar Maklumat di Media Sosial, https://www.bharian.com.my/berita/nasional/2018/03/397326/amal-3r-sebelum-sebar-maklumat-dimedia-sosial.

10. Portal Rasmi SKMM. Akta Komunikasi dan Multimedia 1998 [Akta 588]. Diperoleh daripada https://www.mcmc.gov.my/ms/legal/acts/communications-and-multimedia-act-1998-reprint-200.

11. Tully, C. J. (2003). Growing Up in Technological Worlds: How Modern Technologies Shape the
Everyday
Lives
of Young
People.
Diperoleh
daripada https://www.dji.de/fileadmin/user_upload/bibs/0_2170sagepub.pdf. 